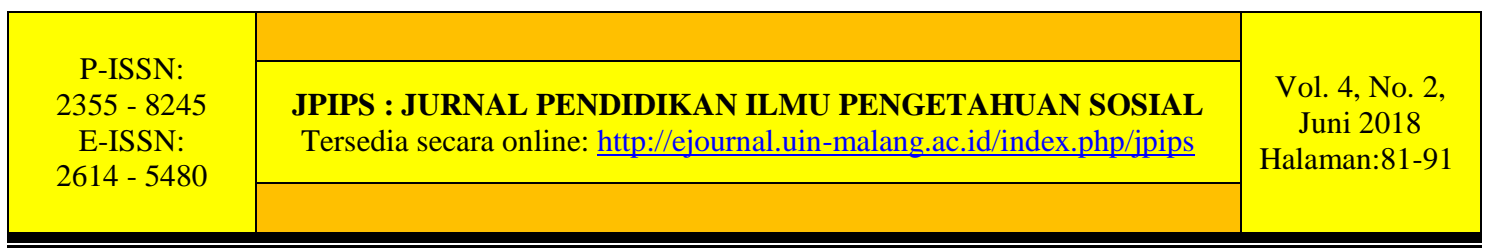

\title{
PENGELOLAAN KEUANGAN MASJID SEBAGAI ORGANISASI NIRLABA
}

\author{
Kusumadyahdewi \\ Universitas Islam Negeri Maulana Malik Ibrahim Malang \\ kusumadyahdewi@pips.uin-malang.ac.id
}

\begin{abstract}
Abstrak: Masjid merupakan lembaga nirlaba, yang banyak menyelenggarakan kegiatan-kegiatan keagamaan, sosial, pendidikan dan dakwah. Aktivitas yang diselenggarakan tergantung pada banyak sedikitnya dana yang diperoleh dari masyarakat sebagai sumber dana masjid. Berdasarkan hasil penelitian, sumber dana masjid diperoleh dari kotak amal yang tertempel di dinding masjid terdiri dari pembangunan masjid, infaq masjid, yang berhak menerima, yatim piatu, dan dhuafa. Selain itu juga dari kotak amal ketika sholat Jumat, donatur tetap dan tidak tetap. Berdasarkan uang yang diperoleh tersebut, masjid mengadakan kegiatan-kegiatan sosial, pendidikan dan dakwah. Sebagai pertanggungjawaban pengurus kepada masyarakat, laporan pemasukan dan pengeluaran keuangan setiap bulan selalu ditempel di papan pengumuman masjid, sehingga semua bisa melihat pelaporannya. Selain itu juga mengirim laporan keuangan khusus kepada donatur tetap. Transparansi keuangan inilah yang memudahkan masjid untuk menggalang dana dari masyarakat. Penyusunan laporan keuangan masjid ini melibatkan bendahara dan staf harian, dengan diketahui oleh ketua takmir masjid sebagai penanggungjawab. Sebagai organisasi masyarakat, masjid ini juga dipantau langsung oleh masyarakat dengan mempublikasikan laporan keuangannya.
\end{abstract}

\section{Kata Kunci : Masjid, keagamaan, sosial, pendidikan, dakwah}

Abstract: The mosque is a non-profit institution, which organizes many religious, social, educational and da'wah activities. The activities held to depend on a lot of funds obtained from the community as a source of mosque funding. Based on the results of the study, the sources of mosque funding were obtained from charity boxes attached to the walls of the mosque consisting of the construction of mosques, infaq of mosques, those entitled to receive, orphans, and the poor. Also from the charity box during Friday prayers, regular and non-permanent donors. Based on the money obtained, the mosque held social activities, education, and da'wah. As the manager's responsibility to the public, monthly income and expenditure reports are always posted on the mosque's bulletin board so that all can see the report. Besides, it also sends special financial reports to regular donors. This financial transparency makes it easier for mosques to raise funds from the public. The preparation of the mosque's financial report involves the treasurer and daily staff, as is known by the chairman of the mosque's takmir as the person in charge. As a community organization, this mosque is also monitored directly by the public by publishing its financial statements.

Keywords: Mosque, religion, social, education, da'wah 


\section{PENDAHULUAN}

Jenis organisasi berdasarkan operasinya, dibedakan menjadi dua yaitu organisasi yang berorientasi laba dan organisasi nirlaba. Contoh organisasi yang berorientasi laba adalah perusahaan-perusahaan komersil, seperti PT Auto 2000, Tbk, PT Indofood Sukses Makmur, Tbk dan sejenisnya sedangkan organisasi nirlaba contohnya yayasanyayasan yang mengelola lembaga pendidikan dan tempat ibadah. Masjid termasuk organisasi nirlaba dimana keberadaannya tidak untuk mencari keuntungan, melainkan untuk kepentingan umum. Pengelolaan keuangan diperlukan sebagai bentuk pertanggungjawaban pengurus kepada donatur, sehingga laporan keuangan harus dipublikasi. Semakin baik laporan keuangan yang dipublikasikan oleh pengurus masjid, akan semakin menambah kepercayaan donatur kepada pihak masjid.

Masjid merupakan salah satu organisasi nirlaba dalam bidang keagamaan, sesuai dengan Pernyataan Standar Akuntansi Keuangan (PSAK) 45 tahun 2011 tentang organisasi nirlaba, bahwa organisasi nirlaba juga harus dan berhak untuk membuat laporan keuangan dan melaporkan kepada para pemakai laporan keuangan (Ikatan Akuntan Indonesia, 2009). Masjid harus membuat laporan keuangan yang akurat dan memberikan informasinya kepada pengguna laporan keuangan tersebut yaitu para donatur masjid. Untuk dapat membuat laporan keuangan dana masjid dengan akurat dibutuhkan penerapan akuntansi, dan peranan akuntansi disini adalah memperlancar manajemen keuangan dalam fungsinya sebagai alat perencanaan, pengawasan dan pengambilan keputusan. Hal ini juga menjadi jawaban atas ketidakpercayaan masyarakat yang bertanya-tanya tentang laporan keuangan masjid yang selama ini biasanya pencatatannya sangat sederhana dan tidak detil (Andarsari, 2016).

Selain itu, dalam Al-Qur'an juga disebutkan pada surat Al-Baqarah ayat 282 tentang pencatatan keuangan, yaitu: "Wahai orang-orang yang beriman! Apabila kamu melakukan utang piutang untuk waktu yang ditentukan, hendaklah kamu menuliskannya. Dan hendaklah seorang penulis diantara kamu menuliskannya dengan benar. Janganlah penulis menolak untuk menuliskannya sebagaimana Allah telah mengajarkan. Dan hendaklah orang yang berhutang itu mendiktenya, dan hendaklah dia bertaqwa kepada Allah, Tuhannya, dan janganlah dia mengurangi sedikitpun daripada-Nya.Jika yang berhutang itu orang yang yang kurang akalnya atau lemah (keadaannya), atau tidak mampu mendiktenya sendiri, maka hendaklah walinya mendiktekannya dengan benar. Dan dipersaksikanlah dengan dua orang saksi laki-laki di antara kamu. Jika tidak ada (saksi) dua orang laki-laki, maka (boleh) seorang laki-laki dan dua orang perempuan di antara orang-orang yang kamu sukai dari para saksi (yang ada), agar jika yang seorang lupa maka yang seorang lagi mengingatkannya. Dan janganlah saksi-saksi itu menolak apabila dipanggil. Dan janganlah kamu bosan menuliskannya, untuk batas waktunya baik (utang itu) kecil maupun besar. Yang demikian itu, lebih adil di sisi Allah, lebih dapat menguatkan kesaksian, dan lebih mendekatkan kamu kepada ketidakraguan, kecuali jika hal itu merupakan perdagangan tunai yang kamu jalankan di antara kamu, maka tidak ada dosa bagi kamu jika kamu tidak menuliskannya. Dan apabila saksi apabila kamu berjual beli, dan janganlah penulis dipersulit dan begitu juga saksi.Jika kamu lakukan (yang demikian), maka sungguh, hal itu suatu kefasikan pada kamu. Dan bertaqwalah kepada Allah, Allah memberikan pengajaran bagi kepadamu, dan Allah Maha Mengetahui segala sesuatu" (Kementerian Agama RI, 2013). Ayat tersebut menunjukkan bahwa pencatatan dalam setiap transaksi yang berkaitan dengan uang, akan lebih baik apabila dilakukan pencatatan. Demikian pula masjid yang banyak melakukan transaksi, antara pengurus 
dengan jamaah maupun pihak lain. Transaksi yang berkaitan dengan keuangan harus selalu diikuti dengan kegiatan pencatatan dan disertai dengan saksi atau pihak ketiga jika ada.

Pengelolaan keuangan masjid berbeda dengan pengelolaan keuangan pada organisasi yang berorientasi laba, dimana uang yang diperoleh akan menjadi lebih baik jika banyak terserap pada kepentingan umat. Pemasukan yang diperoleh harusnya disalurkan untuk kemamkmuran masjid. Masjid Asy-Syahriyah yang terletak di Jl. Pluto 5A Perumahan Tata Surya Malang, pemasukan diperoleh dari warga perumahan Tata Surya, untuk kemamkmuran masjid dan kepentingan warga sekitar. Laporan keuangan disusun sebulan sekali dengan terinci dan dipublikasikan kepada warga. Peneliti tertarik untuk menganalisis keuangan masjid Asy-Syahriyah ini karena warga begitu antusias menyumbang ketika ada kegiatan masjid, sehingga pemasukan keuangan masjid ini terlihat dalam jumlah yang besar. Peneliti ingin mengetahui bagaimana pengelolaan keuangan masjid Asy-Syahriyah, sehingga jamaah dan masyarakat mudah untuk menyerahkan dananya membantu memakmurkan masjid ini.

\section{METODE}

Penelitian ini adalah penelitian kualitatif dengan mengangkat sebuah fenomena yang terjadi dalam lingkup organisasi masjid Asy-Syahriyah di Malang. Penelitian kualitatif adalah penelitian yang terjadi pada lingkungan sosial yang mencakup pelaku, kejadian, tempat, dan waktu. Keempat cakupan tersebut dinamakan social setting (Aan Komariah dan Djam'an Satori, 2010). Pada penelitian kualitatif peneliti diharuskan untuk lebih fokus pada prinsip dasar fenomena yang terjadi dalam kehidupan sosial, yang nantinya akan dianalisis dengan menggunakan teori yang sudah ada (Bambang dan Melia, 2008) dalam (Silvia dan Ansar, 2011). Penelitian ini dimaksudkan untuk memberikan gambaran dan menganalisis praktik pengelolaan keuangan oleh pengurus masjid.

Lokasi penelitian di Masjid Asy-Syahriyah ini terletak di jalan Pluto nomor 5 A Malang, tepatnya di dalam perumahan Tata Surya. Masjid ini berada di wilayah RT 03 RW 04 Kelurahan Tlogomas Kecamatan Lowokwaru. Lokasi masjid yang berada di tengah-tengah pemukiman, menyebabkan masjid ini dikunjungi banyak masyarakat sekitar.

Penelitian ini menggunakan informan yaitu seseorang yang mempunyai pengetahuan (informasi) tentang objek (sasaran) penelitian, yang lazimnya berkaitan dengan dan atau keadaan kelembagaan, termasuk entitas keagamaan Islam yakni masjid. Informan dalam penelitian ini adalah ketua takmir masjid, bendahara masjid, bagian administrasi dan jama'ah masjid. Teknik pengumpulan data dengan menggunakan observasi langsung dan wawancara mendalam kepada informan, metode penarikan sampel dalam penelitian ini, terutama berkaitan dengan wawancara jamaah masjid AsySyahriyah, menggunakan purposive sampling, yakni sampel yang telah ditetapkan oleh peneliti dengan alasan dan tujuan khusus.

Jenis data yang digunakan adalah data primer dan data sekunder. Data primer merupakan data yang diperoleh dari hasil wawancara dan observasi peneliti kepada informan. Sedangkan data sekunder diperoleh dari dokumen masjid yang telah dipublikasi. Dokumen masjid berupa laporan keuangan dan juga laporan kegiatan yang diadakan masjid, yang biasanya berkaitan dengan hari-hari besar keagamaan. Selain itu juga melakukan studi pustaka, guna mengevaluasi laporan keuangan yang disusun masjid dengan teori yang ada. 
Analisis data memiliki hubungan dengan reduksi data yang merupakan langkah yang dilakukan peneliti dengan cara memilih data yang dianggap penting dan dikumpulkan menjadi satu untuk dikumpulkan menjadi data yang sederhana tetapi bermakna. Selain itu interpretasi data juga dibutuhkan dalam penelitian kualitatif karena data-data yang dikumpulkan akan dikomunikasikan dengan publik melalui tulisan atau laporan yang didukung konsep dan teori yang ada (Silvia Janets dan Muhammad Ansar, 2011).

\section{HASIL DAN PEMBAHASAN \\ Hasil}

\section{Sumber dan Alokasi Dana Masjid Asy-Syahriyah}

Dana masjid diperoleh dari jamaah yang menyumbangkan dananya melalui kotak-kotak yang tersedia di masjid, ataupun jamaah yang menyetor dananya secara rutin melalui petugas masjid, sesuai dengan hasil wawancara yang peneliti lakukan kepada bendahara masjid, Ibu Aini, yang mengatakan: "Kalau dana masjid ini berasal dari warga, terus kotak-kotak amal yang di depan masjid juga kotak yang dikelilingkan waktu sholat Jumat."

Juga hasil wawancara dengan Pak Ainun selaku bagian administrasi yang mengatakan: "Kan ada kotak masjid di depan itu bu. Macem-macem ada kotak pembangunan masjid, infaq masjid, yatim piatu, dhuafa, sama yang berhak menerima. Kalo yang dipake masjid ini ya dari infaq masjid itu. Tapi kadang kalo dananya kurang, ya ambil di pembangunan masjid juga. Kotak itu dihitung sebulan sekali, minimal dihitung 2 orang pengurus masjid. Teros kan juga ada yang dari warga itu rutin tiap bulan ditarik. Dulu nariknya masih 30 ribuan terus lama-lama naik ya karena hargaharga juga naik, ada yang limapuluh ribu ada yang 100 ribu seikhlasnya. Jumlahnya semua 68 orang bu jamaah yang nyumbang rutin. Tapi kalo untuk pembangunan masjid itu Insya Allah, warga selalu ada aja yang nyumbang, kebetulan warga sini gampang gitu lo bu kalo untuk masjid itu. Selain itu kalo hari jumat, kotak amal juga diedarkan ke jamaah itu rata-rata dapatnya yaaa limaratusribuanlah bu. Oiya, kalo pas ada acara seperti Maulid Nabi, tahun baru Muharram itu juga jamaah dan warga sini gampang sekali ditarik sumbangan. Karena kita kan jelas a bu, catatannya ada, terus nanti dipertanggungjawabkan, diberi laporan pemasukan dan pengeluaran itu."

Selain itu peneliti juga mewawancarai Pak Latief sebagai ketua takmir masjid tentang sumber dana masjid, yang mengatakan bahwa: "Dari jamaah tapi kadangkadang ada juga donatur dari luar kota atau luar perumahan. Biasanya saudara dari warga sini yang ada di luar kota. Atau yang dulunya warga sini tapi kemudian pindah rumah, tapi karena sudah donatur rutin, ya tetep nyumbang ke sini. Sama ini kotak amal yang nempel di dinding masjid. Tapi yang dikelola masjid itu kotak yang infaq masjid dan pembangunan masjid. Lainnya itu dikelola yayasan.”

Berdasarkan wawancara dengan bagian keuangan dan administrasi masjid, diperoleh data bahwa sumber dana Masjid Asy-Syahriyah berasal dari:

a. Kotak amal yang tertempel di dinding masjid, yaitu kotak infaq masjid dan kotak pembangunan masjid, sedangkan kotak amal yang lain yaitu untuk yatim piatu, yang berhak menerima, dan dhuafa dikelola oleh yayasan.

b. Kotak amal Jumat, yaitu kotak yang dikelilingkan ketika sholat Jum'at.

c. Donatur tetap, dimana setiap bulan 68 jama'ah masjid menyumbang dengan jumlah yang bervariasi Rp40.000 sampai Rp250.000. 
d. Donatur tidak tetap, yaitu jama'ah yang menyumbang pada bulan tertentu saja, terutama karena ada perayaan hari besar Islam yang diadakan di masjid. Adakalanya dalam satu bulan tertentu jama'ah tidak ada yang menyumbang.

Dana yang telah terkumpul, kemudian dicatat berdasarkan nama penyumbang dan jumlah yang disetor, sedangkan untuk dana dari kotak amal, dihitung secara periodik oleh pengurus. Perhitungan dana dari kotak amal dihitung bersama oleh pengurus masjid, minimal 2 orang pengurus. Berdasarkan hasil observasi, peneliti juga melihat bahwa kotak amal Jumat dihitung setiap selesai sholat jumat, sedangkan kotak amal yang tertempel di dinding masjid dihitung satu bulan sekali. Sedangkan jamaah yang menyumbang, tidak diberikan tanda terima pada saat penyerahan dana, akan tetapi bisa melihat langsung di papan pengumuman atau kiriman laporan keuangan pada akhir bulan. Apabila nama penyumbang tidak tercantum, jamaah dapat bertanya kepada pengurus masjid. Tetapi selama ini belum pernah ada jamaah yang menyumbang tetapi namanya tidak tercatat.

Dana yang telah diterima masjid, digunakan untuk membiayai operasional masjid seperti pembayaran gaji petugas administrasi dan kebersihan, uang transport untuk penceramah, listrik, air, telepon, fotokopi, alat tulis dan keperluan masjid lainnya. Seperti yang disebutkan dari hasil wawancara dengan Bapak Ainun: "Kalo sumbangan rutin dari jamaah yang tiap bulan itu untuk pengeluaran rutin juga, kayak gaji, listrik, air, telpon, parfum, tinta printer, gitu itu bu. Selain itu, biasanya kalo ndak mencukupi dananya dari kotak infaq masjid itu. Atau diambilkan dari kasnya masjid. Kita kan punya kas masjid, itu untuk jaga-jaga." Juga wawancara dengan Ibu Aini yang menyatakan: "Kalau pengeluaran masjid itu ya macam-macam, misalnya gaji untuk tenaga administrasi sama yang bersih-bersih masjid itu rutin. Listrik, air, telpon itu juga rutin ya. Kalau yang ndak rutin itu seperti kalau pas acara peringatan maulid, idul kurban itu biasanya ada makan-makan sama bayar uang transport penceramah." Selain itu juga wawancara dengan Bapak Latief sebagai takmir masjid sebagai berikut: "Kalo itu kan biasanya gini, masjid ada kegiatan apa teros jamaah nyumbang. Atau biasanya bisa juga jamaah pas ada rejeki disetorkan sebagian untuk kemakmuran masjid. Lha yang setornya kalau pas ndak ada acara masjid itu, oleh bendahara disimpan di bank untuk jaga-jaga kalau ada kebutuhan masjid yang mendadak. Lha itu kan pengeluaran masjid itu ada yang rutin seperti untuk kebersihan masjid, untuk mbayar yang ceramah jumat, dan ada yang tidak rutin, seperti renovasi, perayaan hari-hari besar Islam."

Jadi alokasi dana masjid yang diperoleh dari jamaah, dapat dikategorikan sebagai berikut:

1. Pengeluaran rutin, yaitu pengeluaran untuk kepentingan masjid yang selalu ada setiap bulan. Pengeluaran ini diambilkan dananya dari donatur tetap masjid yang disetorkan setiap bulan. Contoh pengeluaran rutin ini yaitu gaji untuk karyawan masjid (sebagai petugas kebersihan dan sebagai petugas administrasi, serta membayar gaji satpam yang berjaga pada saat sholat Subuh), uang transport untuk khatib sholat Jumat dan penceramah sholat Subuh, pembayaran PLN, fotocopy laporan-laporan dan pengumuman untuk pemberitahuan kepada jamaah.

2. Pengeluaran tidak rutin, yaitu pengeluaran yang tidak setiap bulan ada. Dananya diambilkan dari uang kas masjid dan atau dari jamaah secara spontan karena ada kegiatan masjid, seperti untuk perayaan Muharram, Idul Adha, Maulid Nabi yang diadakan setiap tahun. 


\section{Pencatatan Pemasukan dan Pengeluaran Dana Masjid Asy-Syahriyah}

Pengelolaan dana masjid yang masuk, berdasarkan hasil wawancara dengan Bapak latief adalah sebagai berikut: "Jadi bendahara nyatet, terus Pak Ainun biasanya yang bikin laporan secara keseluruhan untuk ditempel di papan pengumuman sama dikirim ke jamaah. Tapi sebelum disebarkan, ya saya lihat dulu laporannya sudah sesuai apa belum gitu." Sedangkan berdasarkan hasil wawancara dengan Ibu Aini selaku bendahara masjid mengatakan: "Ya uang yang diterima itu dari siapa terus langsung dicatat namanya dan besarnya berapa. Nanti akhir bulan direkap siapa saja yang nyumbang sama jumlahnya, terus dijumlahkan total berapa, dilaporkan awal bulan berikutnya. Kotak-kotak amal yang ditempel itu juga dihitung tiap akhir bulan, terus disalurkan menurut keperluannya. Kalau infaq masjid sama pembangunan masjid, selain untuk masjid ini juga untuk masjid lain yang sedang membangun dan memerlukan dana. Kalau dhuafa sama yatim, itu kita sudah salurkan rutin ke yayasan sama orang yang ndak mampu di dinoyo sini, tapi yang ngurusi yayasan Asy-Syahriyah."

Wawancara dengan Bapak Ainun menyatakan bahwa: "Kalo uang yang disumbangkan warga untuk masjid itu kan mesti dicatet, siapa yang nyumbang terus nyumbang berapa. Nanti catetan itu dikirim ke jamaah yang nyumbang sama ditempel di papan depan itu. Jadi meskipun jamaah yang ndak nyumbang juga bisa liat berapa uangnya masjid. Kalo kotak yang di depan itu, juga ada laporannya di papan pengumuman masjid. Berapa jumlah masing-masing kotak itu ditulis di situ."

Berdasarkan hasil wawancara dari pengurus masjid di atas dapat disimpulkan bahwa dana yang masuk ke masjid diterima oleh bendahara masjid, kemudian dicatat nama penyumbang dan jumlah sumbangannya. Namun berdasarkan hasil observasi peneliti, pengurus masjid tidak memberikan kuitansi atau tanda terima kepada donatur. Sedangkan untuk kotak amal yang ditempel di dinding masjid dibuka sebulan sekali, dihitung dan dicatat jumlahnya. Selain itu juga kotak amal Jumat yang dibuka setiap selesai sholat Jumat, dihitung jumlahnya dan dicatat. Total penerimaan dijumlahkan kemudian dicantumkan dalam laporan bulanan.

Setiap pemasukan dana ke masjid dilakukan pencatatan nama donatur dan jumlahnya. Demikian juga ketika melakukan pengeluaran, pembelian barang-barang selalu disertai dengan bon sebagai dasar untuk pencatatan keuangan masjid.

Hasil observasi peneliti menunjukkan bahwa pencatatan pemasukan dana dari jamaah selalu dicatat oleh bendahara. Demikian juga pemasukan dari kotak amal, dicatat jumlahnya ketika selesai perhitungan. Sehingga dapat ditarik kesimpulan bahwa alur pencatatan pemasukan dan pengeluaran uang masjid Asy-Syahriyah adalah sebagai berikut:

1. Donatur menyerahkan uangnya kepada bendahara, kemudian bendahara mencatat nama dan jumlah uangnya.

2. Dana dari kotak amal, dihitung secara periodik oleh dua orang atau lebih, kemudian diserahkan ke bendahara dan dicatat berdasarkan nama kotak amal dan masingmasing jumlahnya.

3. Uang yang terkumpul digunakan untuk membiayai operasional masjid, baik pengeluaran rutin maupun yang tidak rutin.

4. Setiap melakukan pembelian, menyerahkan bon pembelian kepada bendahara, kemudian dicatat.

5. Pada akhir bulan dijumlahkan pemasukan dana, dari jamaah dan kotak amal, kemudian dikurangi dengan pengeluaran untuk operasional masjid. 
6. Jika dananya kurang, diambilkan dari kas masjid, sebaliknya jika lebih akan menambah kas masjid.

7. Laporan keuangan yang telah disusun diperiksa kembali oleh ketua takmir.

8. Jika telah sesuai, akan ditempel di papan pengumuman dan dikirim ke beberapa jamaah.

\section{Pengawasan atas Laporan Keuangan Masjid Asy-Syahriyah}

Laporan keuangan yang telah disusun oleh pengurus masjid, menjadi tolok ukur atas kinerja yang telah dicapai. Pengukuran kinerja laporan keuangan masjid AsySyahriyah dilakukan oleh takmir dan jamaah, sesuai dengan yang dipaparkan oleh Bapak Latief sebagai berikut: "Ya kan dari bendahara ada catatannya, terus dibuat sama bagian administrasi, Pak Ainun tadi untuk dipublikasikan, ditempel di papan pengumuman sama dikirim ke jamaah. Nah, dari situ kan jamaah bisa ngecek, uang yang disumbangkan sdh ada di catatan atau tidak, terus untuk pengeluaran masjid berupa apa saja itu ada semua. Kalo ada yang keberatan biasanya disampaikan langsung ke saya atau pengurus masjid yang lain."

Senada dengan yang disampaikan oleh Ibu Aini: "O iya catatan yang dibuat tadi itu, pemasukan sama pengeluaran itu, difotokopi dikirimkan ke jamaah sama ditempel di papan pengumuman masjid. Jadi semua jamaah bisa melihat uangnya digunakan untuk apa saja, kurang apa ndak jadi tau. Itu kan juga untuk kalo misalnya uang masjid kurang jamaah tau terus ada jamaah yang nambahi sehingga kemakmuran masjid tetap terjamin."

Juga yang disampaikan oleh Bapak Ainun: "Yang ngawasi ya jamaah sendiri. Kan sudah dikirim, ditempel di papan, jadi ya sangat terbuka ke jamaah. Misalnya kalo ada yang salah, ya jamaah biasanya langsung ke takmir, atau bu aini atau saya, wong tiap hari kan pengurus ini mesti ke masjid sholat berjamaah."

Laporan keuangan masjid yang berupa catatan pemasukan dan pengeluaran, yang dibuat oleh bendahara masjid, selalu ditempel di papan pengumuman masjid setiap akhir bulan. Selain itu juga dikirimkan kepada pengurus masjid, dan beberapa jamaah tetap masjid Asy-Syahriyah. Publikasi laporan keuangan masjid ini dimaksudkan supaya jamaah mengetahui pemanfaatan uang yang telah didonasikan ke masjid. Jamaah tentunya berharap uang yang telah disumbangkan digunakan sepenuhnya untuk kemakmuran masjid. Masjid Asy-Syahriyah belum sepenuhnya menggunakan uang jamaah atau donatur untuk kepentingan masjid, tetai sebagian disisihkan untuk berjagajaga jika ada kepentingan mendadak. Sebenarnya jamaah keberatan dengan hal ini, tetapi ketika diberi pengertian oleh pengurus masjid, mereka menerima alasan dari pengurus masjid. Pengawasan keuangan masjid, selain diawasi oleh jamaah juga dilakukan oleh takmir masjid sebagai penanggungjawab.

\section{Sumber dan alokasi dana masjid}

\section{Pembahasan}

Kegiatan masjid sangat bergantung pada keaktifan dan inisiatif pengurus masjid, yang tentu saja didukung oleh masyarakat sekitar atau jamaah masjid, karena semakin banyak kegiatan masjid, juga dibutuhkan dana untuk penyelenggaraannya. Jamaah diharapkan menyumbangkan dananya untuk kegiatan masjid ini, sehingga dapat terselenggara dengan baik. Kegiatan masjid ini perlu diadakan untuk kemakmuran masjid, sehingga banyak masyarakat yang memanfaatkan masjid untuk pelaksanaan ibadahnya. Sumber dana masjid tidak hanya mengandalkan dari jamaah saja, tetapi 
masjid juga bisa mengusahakan dari sumber lain, seperti yang disebutkan oleh Siswanto (2002) bahwa sumber dana masjid diperoleh dari:

a. Donatur tetap, yang terdiri dari jamaah atau masyarakat yang secara rutin menyumbang dalam jangka waktu tertentu, biasanya sebulan sekali.

b. Donatur tidak tetap, terdiri dari berbagai pihak yang menyumbang karena adanya permohonan dari pihak masjid.

c. Donatur bebas, terdiri dari jamaah atau pihak lain yang menyumbangkan dananya ke masjid ketika ada kegiatan atau perayaan tertentu.

d. Usaha ekonomi, dalam hal ini masjid mempunyai unit usaha sendiri dalam perdagangan produk atau jasa untk membiayai kegiatan masjid.

Sumber dana masjid berasal dari jamaah dan masyarakat yang berupa infaq dan shadaqah. Jamaah dan masyarakat bisa menyerahkan secara langsung ke masjid dan atau memasukkan dananya ke kotak amal yang tersedia di masjid. Sumber dana masjid berasal dari jamaah, melalui kesadaran masyarakat sekitar untuk memakmurkan masjidnya. Sumber dana masjid Asy-Syahriyah berasal dari:

a. Kotak amal yang tertempel di dinding masjid, yaitu kotak infaq masjid dan kotak pembangunan masjid, sedangkan kotak amal yang lain yaitu untuk yatim piatu, yang berhak menerima, dan dhuafa dikelola oleh yayasan.

b. Kotak amal Jumat, yaitu kotak yang dikelilingkan ketika sholat Jum'at.

c. Donatur tetap, dimana setiap bulan 68 jama'ah masjid menyumbang dengan jumlah yang bervariasi Rp40.000 sampai Rp250.000.

d. Donatur tidak tetap, yaitu jama'ah yang menyumbang pada bulan tertentu saja, terutama karena ada perayaan hari besar Islam yang diadakan di masjid. Adakalanya dalam satu bulan tertentu jama'ah tidak ada yang menyumbang.

Jika dikaitkan dengan pendapat Siswanto, masjid Asy-Syahriyah masih belum ada usaha ekonomi. Jadi untuk sumber dana masih mengandalkan dari jamaah dan non jamaah. Sedangkan alokasi dana masjid yang diperoleh dari jamaah, digunakan untuk pengeluaran yang dapat dikategorikan sebagai berikut:

1. Pengeluaran rutin, yaitu pengeluaran untuk kepentingan masjid yang selalu ada setiap bulan. Pengeluaran ini diambilkan dananya dari donatur tetap masjid yang disetorkan setiap bulan. Contoh pengeluaran rutin ini yaitu gaji untuk karyawan masjid (sebagai petugas kebersihan dan sebagai petugas administrasi, serta membayar gaji satpam yang berjaga pada saat sholat Subuh), uang transport untuk khatib sholat Jumat dan penceramah sholat Subuh, pembayaran PLN, fotocopy laporan-laporan dan pengumuman untuk pemberitahuan kepada jamaah.

2. Pengeluaran tidak rutin, yaitu pengeluaran yang tidak setiap bulan ada. Dananya diambilkan dari uang kas masjid dan atau dari jamaah secara spontan karena ada kegiatan masjid, seperti untuk perayaan Muharram, Idul Adha, Maulid Nabi yang diadakan setiap tahun.

\section{Pencatatan Pemasukan dan Pengeluaran Dana Masjid}

Masjid merupakan organisasi nirlaba yang dananya berasal dari masyarakat, sehingga laporan keuangan yang disusun juga harus terbuka kepada masyarakat sebagai donatur, agar diketahui secara terbuka untuk apa saja dana yang telah diserahkan. Dana yang terkumpul, kebanyakan digunakan untuk kepentingan operasional masjid. Selain itu juga untuk membiayai kegiatan masjid, yang berkaitan dengan perayaan hari besar Islam, seperti maulid Nabi, bulan Ramadhan, Tahun Baru Muharram dan Isra'Mi'raj. 
Semakin terbuka masjid melaporkan keuangannya, jamaah dan masyarakat akan semakin tidak ragu untuk menyumbangkan dananya ke masjid tersebut.

Pengendalian internal masjid sangat penting dilakukan untuk mendapatkan laporan keuangan yang baik ketika dipublikasi sehingga jamaah dan masyarakat tidak akan keberatan untuk menyumbangkan dananya (Said, 2013). Pengendalian internal disini adalah pengawasan dalam melaporkan transaksi yang terjadi di masjid, seperti penerimaan dana dari masyarakat, pencatatan transaksi keuangan dan otorisasinya. Bersamaan dengan pengawasan yang baik akan tersusun laporan keuangan yang baik pula, dan akan berpengaruh dalam penggalangan dana masjid. Sedangkan menurut Supriyono (2000) organisasi nirlaba adalah perusahaan yang tidak membagikan keuntungan kepada orang sekitarnya, tetapi memberikan manfaat. Masjid menyusun laporan keuangan bukan untuk mengetahui laba yang diperoleh tetapi untuk melaporkan kepada jamaah bahwa uang yang diperoleh adalah untuk keperluan masjid. Prosedur dalam melakukan pengeluaran dana masjid, sebagai berikut (ICMI Orsat Cempaka Putih, 2004):

- Setiap pelaksanaan kegiatan yang memerlukan dana diajukan kepada bendahara.

- Pengeluaran dana dapat berbentuk kas, transfer maupun cek/bilyet giro.

- Pengeluaran dana harus sesuai dengan kewenangan batas otoritas.

- Setiap pengeluaran harus mempunyai bukti resmi.

- Dalam mengajukan kebutuhan dana untuk kegiatan ditujukan kepada seksi sebagai penanggungjawab kegiatan.

- Setiap pengajuan yang bersifat mendadak atau selain dalam program kerja maka pengajuan harus kepada ketua masjid.

- Pencatatan pengeluaran dana harus sesuai dengan klasifikasinya.

Berdasarkan hasil wawancara dan oservasi peneliti, alur pencatatan pemasukan dan pengeluaran uang masjid Asy-Syahriyah adalah sebagai berikut:

1. Donatur menyerahkan uangnya kepada bendahara, kemudian bendahara mencatat nama dan jumlah uangnya.

2. Dana dari kotak amal, dihitung secara periodik oleh dua orang atau lebih, kemudian diserahkan ke bendahara dan dicatat berdasarkan nama kotak amal dan masingmasing jumlahnya.

3. Uang yang terkumpul digunakan untuk membiayai operasional masjid, baik pengeluaran rutin maupun yang tidak rutin.

4. Setiap melakukan pembelian, menyerahkan bon pembelian kepada bendahara, kemudian dicatat.

5. Pada akhir bulan dijumlahkan pemasukan dana, dari jamaah dan kotak amal, kemudian dikurangi dengan pengeluaran untuk operasional masjid.

6. Jika dananya kurang, diambilkan dari kas masjid, sebaliknya jika lebih akan menambah kas masjid.

7. Laporan keuangan yang telah disusun diperiksa kembali oleh ketua takmir.

8. Jika telah sesuai, akan ditempel di papan pengumuman dan dikirim ke beberapa jamaah.

Laporan keuangan yang dihasilkan pengurus masjid Asy-Syahriyah ini tergolong sederhana karena hanya melaporkan arus kas saja, yang terdiri dari pemasukan dan pengeluaran saja. Akan tetapi pelaporan ini dapat diterima oleh jamaah dan masyarakat sekitar karena penyajiannya yang sederhana sehingga mudah dipahami semua kalangan. Hal ini menyebabkan jamaah mempercayai pengurus masjid dan ketika ada kebutuhan dana masjid, jamaah dengan segera akan menyumbangkan dananya. Akan tetapi untuk 
jamaah dan masyarakat yang menyumbangkan dananya belum ada tanda terima yang dapat dijadikan bukti penerimaan dana oleh masjid. Pelaporan keuangan masjid yang sederhana juga dikemukakan dalam penelitian sebelumnya, sehingga rata-rata masjid masih menyajikan laporan keuangan dalam bentuk sederhana, yaitu melaporkan pemasukan dan pengeluaran saja, tanpa ada laporan tentang asset yang dimiliki masjid.

\section{Pengawasan Keuangan Masjid}

Pelaporan keuangan adalah untuk menyajikan transaksi yang terjadi dalam suatu organisasi. Masjid termasuk organisasi nirlaba, yang sumber dananya diperoleh dari masyarakat. Perolehan sumber dana dialokasikan untuk kepentingan masjid, supaya jamaah nyaman ketika beribadah di masjid, atau untuk mendukung kegiatan-kegiatan masjid agar tetap dikunjungi jamaahnya. Laporan keuangan masjid umumnya terdiri dari pemasukan dan pengeluaran, yang dibuat secara sederhana, dengan maksud agar jamaah dengan mudah memahami dan mengetahui alokasi dana yang diperoleh masjid. Sehingga semakin baik pelaporan keuangan masjid, jamaah akan semakin percaya dan menyumbangkan dananya.

Pengendalian internal yang baik dan keterlibatan pengurus masjid dalam penggalangan dana akan meningkatkan kinerja keuangan masjid. Sehingga kinerja keuangan yang baik akan meningkatkan kepercayaan jamaah dalam mendanai kegiatan masjid. Oleh karenanya, sangat penting untuk pengurus masjid merumuskan strategi manajemen memperbaiki kinerja masjid supaya menghasilkan program yang jelas, sehingga memudahkan dalam penggalangan dana dari jamaah (Said, 2013).

Laporan keuangan masjid Asy-Syahriyah yang berupa catatan pemasukan dan pengeluaran, yang dibuat oleh bendahara masjid, selalu ditempel di papan pengumuman masjid setiap akhir bulan. Selain itu juga dikirimkan kepada pengurus masjid, dan beberapa jamaah tetap masjid Asy-Syahriyah. Publikasi laporan keuangan masjid ini dimaksudkan supaya jamaah mengetahui pemanfaatan uang yang telah didonasikan ke masjid. Jamaah tentunya berharap uang yang telah disumbangkan digunakan sepenuhnya untuk kemakmuran masjid. Masjid Asy-Syahriyah belum sepenuhnya menggunakan uang jamaah atau donatur untuk kepentingan masjid, tetapi sebagian disisihkan untuk berjaga-jaga jika ada kepentingan mendadak. Sebenarnya jamaah keberatan dengan hal ini, tetapi ketika diberi pengertian oleh pengurus masjid, mereka menerima alasan dari pengurus masjid. Pengawasan keuangan masjid, selain diawasi oleh jamaah juga dilakukan oleh takmir masjid sebagai penanggungjawab. Transparansi atau keterbukaan pihak masjid kepada jamaah atas laporan keuangan ini, akan mempermudah masjid dalam mobilisasi dana dari masyarakat sekitar dan jamaah.

\section{KESIMPULAN}

Berdasarkan hasil wawancara dan observasi dalam penelitian ini, dapat disimpulkan bahwa:

1. Sumber dana masjid diperoleh dari kotak amal dan donatur masjid, yang terdiri dari donatur tetap dan tidak tetap. Sedangkan alokasinya adalah untuk kemakmuran masjid, yang terdiri dari pengeluaran rutin dan tidak rutin. Fungsi perencanaan dalam manajemen, tidak dilakukan oleh pengurus masjid Asy-Syahriyah untuk pengeluaran sehari-hari, tetapi perencanaan untuk kegiatan-kegiatan masjid berkaitan dengan perayaan hari besar Islam dilakukan untuk penggalangan dana.

2. Pelaporan keuangannya, yaitu dengan mengurangi jumlah pemasukan dan pengeluaran. Jika ada kekurangan, masjid akan mengambil dari kas masjid, dan jika 
ada kelebihan dimasukkan ke tabungan masjid. Jadi masjid ini masih memiliki uang tabungan, yang artinya uang jamaah tidak digunakan sepenuhnya sampai habis, tetapi ada sisa. Hal ini yang membuat jamaah keberatan, akan tetapi pengurus masjid mengemukakan bahwa tabungan tersebut untuk berjaga-jaga jika pemasukan rutin dari jamaah tidak mencukupi untuk pengeluaran rutin masjid. Berdasarkan pengamatan peneliti dari laporan keuangan bulanan, memang pemasukan rutin dari jamaah tidak mencukupi untuk pengeluaran rutin masjid. Sehingga jamaah mau menerima alasan tersebut.

3. Laporan keuangan yang telah tersusun, diperiksa kembali oleh ketua takmir, kemudian baru ditempel di papan pengumuman masjid dan dikirim ke jamaah donatur tetap. Laporan keuangan yang terbuka dan diumumkan secara terbuka oleh pengurus masjid menunjukkan pertanggungjawaban pengurus masjid terhadap dana masyarakat dan jamaah. Keterbukaan ini juga memudahkan masjid untuk menggalang dana dari masyarakat karena dipercaya.

\section{DAFTAR PUSTAKA}

Aan Komariah dan Djam'an Satori. (2010). Metodologi Penelitian Kualitatif. Bandung: Alfabeta.

ICMI Orsat Cempaka Putih. (2004). Pedoman Manajemen Masjid. Jakarta: Departemen Agama.

Ikatan Akuntan Indonesia. (2009). Standar Akuntansi Keuangan, PSAK No. 45: Penyajian Laporan Keuangan. Jakarta : Salemba Empat.

Ikatan Akuntansi Indonesia. (2009). Standar Akuntansi Keuangan, PSAK No. 1 : Penyajian Laporan keuangan. Jakarta : Salemba Empat.

Kementerian Agama RI. (2013). Al-Quran. Jakarta: PT Sapta Sentosa.

Pipit Rosita Andarsari. (2016). Laporan Keuangan Organisasi Nirlaba (Lembaga Masjid). Jurnal Ekonomi Kediri. Vol. 1. No. 2, September 2016.

Said, Jamaliah. (2013). Financial Management Practices in Religious Organizations: An Empirical Evidence of Mosque in Malaysia. International Business Research: Vol. 6, No. 7. Published by Canadian Center of Science and Education

Silvia Janets dan Muhammad Ansar. (2011). Akuntabilitas dalam Perspektif Gereja Protestan. Aceh: SNA 14.

Siswanto. (2002). Panduan Pengelolaan Himpunan Jama'ah Masjid. Jakarta: Pustaka Amani.

Supriyono, R.A, (2000). Akuntansi Biaya: Perencanaan dan Pengendalian Biaya serta Pembuatan Keputusan. Yogyakarta. 